\title{
Research on the Factors Affecting Analysts' Tracking and Infringement of Listed Companies
}

\author{
Xiao Zhang ${ }^{1}$, Yi Wang ${ }^{1}$ \\ ${ }^{1}$ School of Finance, Zhongnan University of Economics and Law, Wuhan, Hubei, 430070
}

Keywords: Analyst tracking; company violations; equity nature; institutional investors

\begin{abstract}
This paper takes the 2007-2016 data of China's Shanghai and Shenzhen A-shares as the research object, adopts Probit and Bivariate Probit estimation methods, and discusses the factors affecting analysts' tracking and violation of listed companies based on the nature of equity and institutional investors. The study found that analysts' tracking of corporate violations is stronger in state-owned enterprises, but the relationship between analysts and company audits is not affected by the nature of the company's equity; in companies with a high proportion of institutional investors, the more obvious the role of analysts in suppressing corporate violations.
\end{abstract}

\section{Introduction}

Analysts play an increasingly important role as an external corporate governance mechanism. As an increasingly important participant in the capital market, securities analysts follow up on stock selection, analyze statements, forecast future trends, issue stock ratings, conduct industry stock recommendation, etc., which greatly affects the information asymmetry between investors and listed companies. The mitigation effect enhances investors' understanding of the industry and listed companies. In recent years, the violations of listed companies in China have been frequent, and the legitimate rights and interests of investors cannot be fully guaranteed. Studies have found that analyst tracking can detect the company's abnormal activities in a timely manner and have a certain inhibitory effect on corporate violations (Yu, 2008; Wiesenfeld et al., 2008; Dyck et al., 2010). For Chinese listed companies, on the one hand, there are obvious differences between state-owned enterprises and non-state-owned enterprises in corporate governance, information disclosure, personnel appointment and financing environment. On the other hand, institutional investors, as an important service target for analysts, have an important impact on analysts' income and ratings. Therefore, this paper deeply studies the heterogeneity of corporate equity and how institutional investors' shareholding affects the relationship between analysts tracking and violations of listed companies. The conclusions of this paper enrich the literature in related fields such as analysts and corporate violations, and have certain significance for understanding how analysts can supervise corporate violations and promote the healthy development of the company.

\section{Theoretical analysis and hypothesis proposed}

\subsection{The impact of the nature of equity on analysts' tracking and violations of listed companies}

Chinese state-owned enterprises and non-state-owned enterprises have significant differences in corporate governance, information disclosure, personnel appointment, and financing environment. On the one hand, state-owned enterprises have a low level of information disclosure and serious information asymmetry. Analysts are more cautious and in-depth on the research and analysis of state-owned enterprises. In addition, the management of state-owned enterprises must consider the maximization of company profits. Pay more attention to the fulfillment of social responsibility, but also pay more attention to personal reputation and company reputation (Cai Zhiyue, Wu Shinong, 2007). Therefore, state-owned enterprises pay more attention to the opinions and reports issued by analysts, and the corresponding tendency to violate the rules is even lower. On the other hand, due to the government background, the problem of rigid redemption is more serious, and it is easier to 
integrate funds through borrowing and other means in the market; the external financing environment faced by private and foreign-funded enterprises is even more severe (Chen et al. , 2016), non-state-owned enterprises will pay more attention to maintaining the company's external reputation, in order to rely on analysts to promote corporate image to optimize the financing environment, the probability of violations is even lower. Based on the above analysis, this paper proposes two competitive hypotheses $1 \mathrm{a}$ and $1 \mathrm{~b}$ to be tested:

Hypothesis 1a: Analysts track the suppression of corporate irregularities in state-owned companies.

Hypothesis 1b: Analysts track the suppression of corporate irregularities in non-state-owned enterprises,

After the company violates the rules, will the analysts treat the company differently according to the nature of the company's equity? This paper believes that the impact of analysts on the company's violation audit probability is not affected by the nature of state-owned enterprises. If analysts adopt the practice of concealing violations and reducing the probability of violations, they have no incentive to treat state-owned enterprises and private enterprises and foreign investment. There is no profit available. Therefore, this paper proposes the following hypothesis 2:

Hypothesis 2: The relationship between the analyst and the company's violation audit is not affected by the nature of the company's equity.

\subsection{The influence of institutional investors on the tracking of analysts' violations with listed companies}

Studies have shown that institutional investors are an effective external governance mechanism that can inhibit corporate violations (Lu Yao et al., 2012). As an important service target of analysts, institutional investors have an important influence on analysts' income and ratings. If institutional investors increase the transactions conducted by analysts in the brokerage seats, the more commission income the analysts will receive. And institutional investors have voting rights on the assessment results of new wealth star analysts, so institutional investors will seriously affect the analyst's report objectivity (Li Xindan et al., 2008; Li Dan et al., 2016). Zhu Weidong et al. (2016) found that due to the pressure from institutional investors, the analysis report of the analysis tends to be optimistic. Based on the above analysis, it can be inferred that in the attitude of the analysts responsible for institutional investors, the analysts will pay more attention to the in-depth analysis of listed companies with higher proportion of institutional investors, thus inhibiting the occurrence of corporate violations to a large extent; For listed companies with a high proportion of institutional shareholdings, in order to reduce the losses of most institutional investors after the company violates regulations, analysts tend to conceal the facts of company violations. Therefore, this paper proposes the following hypothesis to be tested:

Hypothesis 3: The higher the proportion of institutional investors, the stronger the inhibitory effect of the company on the company's tendency to violate the rules.

Hypothesis 4: The higher the proportion of institutional investors, the more analysts can reduce the company's violations

Probability.

\section{Research design}

\subsection{Sample selection and data source}

This paper takes the 2007-2016 data of Shanghai and Shenzhen A-shares as the research object, and conducts preliminary screening of data in the following order: (1) Excluding listed companies in the financial industry; (2) Excluding companies with missing sample data; (3) Excluding all continuous variables 1\% and 99\% level of tailing treatment. Finally, 16410 valid annual observation sample data were obtained. The data in this paper comes from the CSMAR database and the RESSET database, and uses Stata software for related data processing. 


\subsection{Model setting and variable selection}

This paper draws on the methods of Poirier (1976), Lu Yao et al. (2012) and Wan Liangyong (2014) to study the Probit and Bivariate Probit models respectively. First set the model (1) using the Probit method for regression, where Zit indicates company violations. The models (2a) and (2b) were set up and a more detailed study was carried out using the Bivariate Probit method, where Ana represents the analyst tracking variable and was replaced with InAna and ISAna when estimated. In order to test the nature of equity and the heterogeneity of institutional investors in the follow-up of analysts to curb corporate violations, this paper respectively added the transfer term. Moderator represents the regulatory variable. When analyzing the impact of the nature of equity, it is replaced by the nature of corporate equity (SOE), where SOE is 1 for state-owned enterprises; otherwise, it is for non-state-owned enterprises to test the coefficient of Ana*SOE. In analyzing the impact of the institutional investor ratio (Inst), take the sum of the institutional investors' shareholdings to test the coefficient of Ana*Inst. The definition and measurement of specific variables are shown in Table 1.

$Z \_\mathrm{it}=\beta \_0+\beta \_1$ Ana $+\beta \_2$ Ana*Moderator $+\beta \_3$ Moderator $+\beta \_4$ pinddir $+\beta \_5$ shrcr5 $+\beta \_6$ lnassets $+\beta_{-} 7$ bothdc $+\beta \_8$ Return $+\beta \_9$ pstateshr $+\beta \_10$ Auditor4 $+\beta \_11 \quad$ lev $+\beta \_12$ A3Growthrate $+\beta \_13$ AvgDtrdTurnR $+\beta \_14$ TobinQ $+\varepsilon_{-}$it( 1$)$

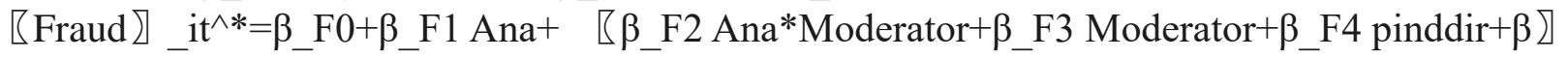
_F5 shrcr5

$+\beta \_$F6 lnassets $+\beta \_$F7 bothdc $+\beta \_$F8 Return $+\beta \_F 9$ pstateshr $+\beta \_$F10 Auditor $4+\mu \_$it $(2 a)$

[Detect $\ \mathrm{it}^{\wedge *}=\beta \_D 0+\beta \_\mathrm{D} 1$ Ana $+\beta \_\mathrm{D} 2$ Ana*Moderator $+\beta \_\mathrm{D} 3$ Moderator $+\beta \_\mathrm{D} 4$ lev $+\beta \_\mathrm{D} 5$ A3Growthrate+ $\beta \_D 6$ AvgDtrdTurnR+ $\beta \_D 7$ TobinQ+ $\beta \_D 8$ pstateshr+ $\beta$ _D9 Auditor4+v_it (2b)

Table 1 Definition and measurement of variables

\begin{tabular}{|c|c|c|}
\hline Variable type & Variable symbol & Variable definitions \\
\hline $\begin{array}{l}\text { Explained variable } \\
\text { variable }\end{array}$ & Vio & $\begin{array}{l}\text { The dummy variable is taken when the company is found out of the violation in } \\
\text { the same year. }\end{array}$ \\
\hline \multirow{4}{*}{ Explanatory variables } & $\ln A n a$ & $\begin{array}{l}\ln A n a=\ln (\text { AnaAttention+1), AnaAttention is the attention of the analyst. It is the } \\
\text { logarithm of the company's tracking analysis by the analyst (team). The number } \\
\text { of members is not listed separately. }\end{array}$ \\
\hline & ISAna & $\begin{array}{l}\text { The dummy variable, the company has } 1 \text { track of the analyst team in the year, } \\
\text { otherwise it is } 0 \text {. }\end{array}$ \\
\hline & SOE & $\begin{array}{l}\text { The nature of the equity property is } 1 \text { when the actual controller of the company } \\
\text { is the country; when the actual controller is private, foreign or other, it is } 0 \text {. }\end{array}$ \\
\hline & Inst & Total share of institutional investors \\
\hline \multirow{11}{*}{ Control variable } & pinddir & Company's proportion of independent directors \\
\hline & shrcr5 & The sum of the shareholding ratio of the top 5 major shareholders of the company \\
\hline & lnassets & $\begin{array}{l}\text { The size of the company is the logarithm of the company's total assets (million } \\
\text { yuan) }\end{array}$ \\
\hline & bothdc & $\begin{array}{l}\text { The size of the company is the logarithm of the company's total assets (million } \\
\text { yuan) }\end{array}$ \\
\hline & Return & $\begin{array}{l}\text { The size of the company is the logarithm of the company's total assets (million } \\
\text { yuan) }\end{array}$ \\
\hline & pstateshr & $\begin{array}{l}\text { The proportion of state-owned shares, calculation method: number of state-owned } \\
\text { shares / total number of shares }\end{array}$ \\
\hline & Auditor4 & $\begin{array}{l}\text { The proportion of state-owned shares, calculation method: number of state-owned } \\
\text { shares / total number of shares }\end{array}$ \\
\hline & lev & Assets and liabilities \\
\hline & A3Growthrate & $\begin{array}{l}\text { The average growth rate of the company's total operating income over the past } \\
\text { three years }\end{array}$ \\
\hline & AvgDtrdTurnR & $\begin{array}{l}\text { Average daily turnover rate of tradable shares, which is the average daily rate of } \\
\text { tradable shares of the company during the year }\end{array}$ \\
\hline & TobinQ & $\begin{array}{l}\text { Tobin Q value, the calculation method is: [(total number of shares - domestically } \\
\text { listed foreign shares B shares) * today's closing price A share current value }+ \\
\text { current exchange rate * current closing price current value * domestically listed } \\
\text { foreign shares B shares }+ \text { total End of current period liabilities] / total assets }\end{array}$ \\
\hline
\end{tabular}




\section{Analysis of the factors affecting analysts' tracking and violations of listed companies}

\subsection{The impact of the nature of equity on analysts' tracking of violations with listed companies}

The column (1) of Table 2 reports the results obtained by the panel Probit estimation method. The coefficient of the intersection term $\ln A n a * S O E$ is significantly negative at the confidence level of $10 \%$, indicating that compared with non-state-owned enterprises such as private and foreign capital, the state-owned The role of analysts in corporate governance to curb corporate violations is even more pronounced. Columns (2) and (3) of Table 2 report the results obtained by the Bivariate Probit estimation method. The coefficient of the lnAna*SOE of the company is significantly negative for the coefficient of the company's violation tendency (Fraud) at a confidence level of 5\%, indicating Compared with non-state-owned enterprises, analysts in state-owned enterprises have a stronger inhibitory effect on corporate irregularities. The coefficient between the transfer term lnAna*SOE and the company's violation check (Detect) is positive and not statistically significant. Further explanation: Compared with non-state-owned enterprises such as private and foreign-funded enterprises, the inhibitory effect of analysts on corporate irregularities and violations tends to be stronger in state-owned enterprises. This aspect may be due to the fact that in China it is generally relative to non-state-owned enterprises. The information disclosure of enterprises is not very sufficient, and the degree of information asymmetry with investors is higher. Analysts can fully exert their intermediary role in mining information and transmitting information, and the effect of governance is more significant. On the other hand, state-owned enterprises must Considering the maximization of corporate profits, it will pay more attention to the reputation of executives and the legal compliance of corporate behaviors. It will pay more attention to analysts' opinions and research reports that can affect the company's image. The governance effect of analysts' suppression of corporate violations will be stronger. Assuming 1a is verified, it is assumed that $1 \mathrm{~b}$ does not hold. After the company's violations, the nature of the company's equity has no significant impact on the relationship between analysts and violations, indicating that the role of analysts in reducing the probability of auditing is not significantly different between state-owned and non-state-owned enterprises. Hypothesis 2 is established.

Table 2 The effect of equity nature on analyst tracking and violations of listed companies

\begin{tabular}{|c|c|c|c|}
\hline variable & Z (1) & Fraud（2） & Detect（3） \\
\hline \multirow[t]{2}{*}{$\ln A n a$} & $-0.087 * * *$ & -0.063 & $-0.108 * * *$ \\
\hline & $(-4.44)$ & $(-1.24)$ & $(-4.34)$ \\
\hline \multirow[t]{2}{*}{$\ln A n a * S O E$} & $-0.043^{*}$ & $-0.163 * *$ & 0.017 \\
\hline & $(-1.67)$ & $(-2.01)$ & $(0.45)$ \\
\hline \multirow[t]{2}{*}{$\mathrm{SOE}$} & $-0.162 * * *$ & 0.177 & $-0.282 * * *$ \\
\hline & $(-3.16)$ & (1.18) & $(-4.05)$ \\
\hline \multirow[t]{2}{*}{ Constant term } & $-1.601 * * *$ & $-0.759 * *$ & \\
\hline & $(-8.89)$ & $(-2.10)$ & \\
\hline Controlled & Controlled & Controlled & Controlled \\
\hline Number of observations & 16410 & 16410 & 16410 \\
\hline Wald chi2 & 294.257 & 406.012 & \\
\hline $\mathrm{p}>$ chi2 & 0.000 & 0.000 & \\
\hline Loglikelihood & -6020.35 & -6070.55 & \\
\hline
\end{tabular}

4.2 The influence of institutional investors' shareholding on analysts' tracking of violations with listed companies

As a more effective external governance mechanism, institutional investors can reduce the agency costs of companies (Wang et al., 2005) and curb earnings management. Securities analysts are more willing to release more optimistic research reports under the pressure of institutional investors. The column (1) of Table 3 reports the results obtained by the panel Probit estimation method. The lnAna*Inst coefficient of the intersection term is significantly negative at the $5 \%$ 
confidence level, indicating that the analysts increase with the increase in the shareholding ratio of institutional investors. The stronger the inhibition of corporate violations. Columns (2) and (3) of Table 3 report the results obtained by the Bivariate Probit estimation method. The coefficient of the lnAna*Inst of the company is significantly negative at the $10 \%$ level of the company's violation tendency (Fraud), indicating that The increase in the shareholding ratio of institutional investors, the stronger the governance effect of analysts reducing the company's tendency to violate regulations. The transfer term InAna*Inst has a negative coefficient for the company's violation audit, which means that when the institutional investor's shareholding ratio increases, the analyst can reduce the probability of the company's violation being audited, but the cross-impact is statistically Not obvious. Explain that institutional investors will give analysts pressure to reduce corporate violations, but it will not significantly affect the analyst's cover-up effect on corporate violations. This may be because institutional investors are important customers of analysts and voters who judge analysts. For companies with a high proportion of institutional investors, analysts pay more attention to research, and the research is more in-depth and information asymmetrical. To a lesser extent, the likelihood of a company violating the rules is smaller. Hypothesis 3 is verified. Although the coefficient of the lnAna*Inst for the company's violation inspection is not significant, it also shows to some extent that institutional investors will strengthen the analyst's cover-up effect on the company's violations, and the reason may be that after the company violates regulations, it is maintained. In the interests of institutional investors, analysts will try not to speak or collaborate with the company to reduce the probability of being audited. Hypothesis 4 is not verified.

Table 3 The Impact of Institutional Investors' Shareholdings on Analysts' Tracking and Infringement Relations with Listed Companies

\begin{tabular}{c|c|cc}
\hline variable & $\mathbf{Z}$ (1) & Fraud (2) & Detect (3) \\
\hline \multirow{2}{*}{$\ln$ Ana } & -0.040 & -0.001 & -0.047 \\
\cline { 2 - 4 } & $(-1.43)$ & $(-0.01)$ & $(-1.53)$ \\
\hline \multirow{2}{*}{$\ln$ Ana*Inst } & $-0.120^{* *}$ & $-0.263^{*}$ & -0.078 \\
\cline { 2 - 4 } & $(-2.07)$ & $(-1.69)$ & $-1.13)$ \\
\hline \multirow{2}{*}{ Inst } & -0.083 & 0.113 & $(-1.54)$ \\
\cline { 2 - 4 } & $(-0.69)$ & $(0.35)$ & $(5.71)$ \\
\cline { 2 - 4 } & $(5.49)$ & & $-1.469^{* * *}$ \\
\hline Constant term & $-1.662^{* * *}$ & $-0.986^{* *}$ & $(-16.68)$ \\
\cline { 2 - 4 } & $(-9.18)$ & $-2.54)$ & \\
\hline Control variable & Controlled & Controlled & \\
\hline Number of observations & 16410 & 16410 & \\
\hline Wald chi2 & 272.832 & 378.965 & \\
\hline p>chi2 & 0.000 & 0.000 & \\
\hline Loglikelihood & -6032.1 & -6085.97 & \\
\hline
\end{tabular}

\section{Research conclusions and recommendations}

This paper takes the 2007-2016 data of China's Shanghai and Shenzhen A-shares as the research object, and discusses the nature of equity and the influence of institutional investors on the role of analysts. The study found that compared with non-state-owned enterprises such as private and foreign investors, analysts track the tendency of companies to violate regulations. The inhibition is stronger in state-owned enterprises. At the same time, the relationship between analysts and company audits is not affected by the nature of the company's equity; as the proportion of institutional investors increases, analysts' inhibition of corporate violations becomes Stronger. The conclusions of this paper enrich the literature of related fields such as analysts and corporate violations, and have certain significance for understanding the governance role of analysts, how to suppress corporate violations and promote the healthy development of the company.

In order to more effectively play the role of external supervision and management of analysts, 
the regulatory authorities should strengthen supervision and achieve efficient supervision. In view of the stronger role of analysts in the governance of state-owned enterprises and institutional investors, the regulators can strengthen the supervision of listed companies with low shareholding ratio of non-state-owned enterprises and institutional investors. Strength.

\section{References}

[1] Lu Yao, Zhu Yujie, Hu Xiaoyuan. Empirical research on institutional investors' shareholdings and listed company's violations [J]. Nankai Management Review, 2012, (01): 13-23.

[2] Wan Liangyong, Hu Wei. Network location, independent director governance and company mergers and acquisitions - empirical evidence from Chinese listed companies [J]. Nankai Management Review, 2014, (02): 64-73.

[3] Cai Zhiyue, Wu Shinong. Empirical study on the characteristics of the board of directors affecting the violations of listed companies [J]. Nankai Management Review, 2007, 6: 62-68+92.

[4] Li Xindan, Song Surong, Lu Bin, Cha Xiaolei. Research on behavioral motives of insider trading in securities market [J]. Economic Research, 2008, 43(10): 65-79+92.

[5] Li Dan, Yuan Wei, Liao Guanmin. Short Selling Mechanism and Optimistic Bias of Analysts_—_Test Based on Double Difference Model [J]. Accounting Research, 2016, 9:25-31.

[6] Wang Wei, Xiao Xing. Empirical research on the holding of institutional investors and related parties [J]. Nankai Management Review, 2005, 8 (02): 27-33

[7] Dyck A. , Morse A. ,Zingales L. Who Blows the Whistle on Corporate Fraud? [J]. Journal of Finance, 2010, 65(6): 2213-2253.

[8] Wiesenfeld, B. , K. Wurthmann, D. Hambrick. The stigmatization of devaluation of elites associated with corporate failures: A process model [J]. Academy of Management Review, 2008, 33(1), 231-251.

[9] Yu F. Analyst Coverage and Earnings Management [J]. Journal of Financial Economics, 2008, 88(2): 245-271. 